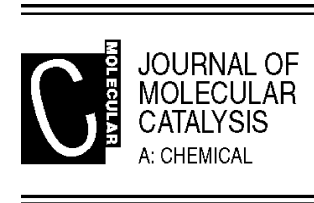

Journal of Molecular Catalysis A: Chemical 145 (1999) 317-321

www.elsevier.com/locate/molcata

Letter

\title{
Fluorous biphasic hydrogenation of 1-alkenes using novel fluorous derivatives of Wilkinson's catalyst
}

\author{
Bodo Richter ${ }^{\mathrm{a}}$, Berth-Jan Deelman ${ }^{\mathrm{b}, *}$, Gerard van Koten ${ }^{\mathrm{a}}$ \\ ${ }^{a}$ Debye Institute, Department of Metal-Mediated Synthesis, Utrecht University, Padualaan 8, 3584 CH Utrecht, The Netherlands \\ ${ }^{\mathrm{b}}$ Elf Atochem Vlissingen, P.O. Box 70, $4380 \mathrm{AB}$ Vlissingen, The Netherlands
}

Received 15 January 1999; accepted 8 February 1999

\begin{abstract}
A novel approach for the easy attachment of fluorous tails to aryl phospines has been developed, leading to a new fluorous alkylsilyl-substituted triaryl phospines $\left.\mathrm{P}_{(} \mathrm{C}_{6} \mathrm{H}_{4} \mathrm{SiMe}_{2} \mathrm{R}_{\mathrm{f}}-4\right)_{3}\left(\mathrm{R}_{\mathrm{f}}=-\left(\mathrm{CH}_{2}\right)_{2}\left(\mathrm{CF}_{2}\right)_{n} \mathrm{CF}_{3} ; n=5,7\right)$. The derived fluorous tris(aryl phospine)rhodium(I) chloride complexes, being fluorous analogs of Wilkinson's catalyst, show high activity in hydrogeneration of 1-alkenes under fluorous biphasic (FBS) conditions and can be effectively recycled. (C) 1999 Elsevier Science B.V. All rights reserved.
\end{abstract}

Keywords: Fluorous phase catalysis; Phosphines; Hydrogenation; Rhodium

\section{Introduction}

Fluorous biphasic catalysis, an alternative to aqueous biphasic catalysis, was originally developed by Horváth et al. as a method for facile catalyst recovery in hydroformylation of 1-alkenes using $\mathrm{HRh}(\mathrm{CO})\left[\mathrm{P}\left\{\left(\mathrm{CH}_{2}\right)_{2}\left(\mathrm{CF}_{2}\right)_{5} \mathrm{CF}_{3}\right\}_{3}\right]_{3}$ as fluorous catalyst $[1,2]$. Since this early report, several other fluorous metal complexes have been prepared. Some of these show activity as catalysts in hydroformylation [1-4], hydroboration [5], hydrogenation [6] and cross-coupling reactions $[7,8]$. To our knowledge, the existing

\footnotetext{
* Corresponding author. Current address: Debye Institute, Department of Metal-Mediated Synthesis, Utrecht University, Padualaan 8, $3584 \mathrm{CH}$ Utrecht, The Netherlands. Fax: +31-30-2523615; E-mail: b.j.deelman@chem.uu.nl
}

arylphosphines with fluorotails are restricted to $m$ - and $p$-substituted triphenylphosphines [9] and $o-, m$-, and $p$-substituted bis(diphenylphosphino)ethane derivatives using either the aryl group itself $[6,10]$ or the $-\mathrm{C}_{6} \mathrm{H}_{4}-\left(\mathrm{CH}_{2}\right)_{2}$ - fragment [3] as a spacer, which is most likely related to synthetic difficulties.

In here, we present (i) a new, versatile synthetic route for the synthesis of fluorous arylphosphines $\mathbf{( 4 a}, \mathbf{b})$ involving the use of the $-\left(\mathrm{CH}_{2}\right)_{2} \mathrm{SiMe}_{2}-$ fragment as a connection between the aryl group and the fluorous tail; (ii) the preparation of Wilkinson's catalyst $[11,12]$ derived fluorous rhodium(I) chloride complexes $(\mathbf{5 a}, \mathbf{b})$; (iii) their activity as catalysts for the hydrogenation of 1-alkenes under fluorous conditions; and (iv) their efficient recycling by facile phase separation. To be able to establish the effect of the tetrahydroperfluoroalkyl sub- 
stituent, trimethylsilyl derivatives $\mathbf{4 c}$ [13] and $\mathbf{5 c}$ were prepared for comparison.

\section{Results and discussion}

The synthesis of compounds $\mathbf{4 a}, \mathbf{b}$ is straightforward and starts from $1 \mathrm{H}, 1 \mathrm{H,2H}, 2 \mathrm{H}$-perfluoro-1-alkyldimethylchlorosilanes $(\mathbf{1 a}, \mathbf{b})$ (Scheme 1). Reaction with $p$-bromophenyllithium yielded the corresponding $p$-bromo( $1 H, 1 H, 2 H, 2 H$-perfluoro-1-alkyl)dimethylsilylbenzenes (2a,b) with $\mathrm{C}_{6} \mathrm{H}_{4}\left[\mathrm{SiMe}_{2}-\right.$ $\left.\left(\mathrm{CH}_{2}\right)_{2}\left(\mathrm{CF}_{2}\right)_{n} \mathrm{CF}_{3}\right]_{2}-1,4(n=5,7)$ as a side product. A similar result was reported in the copper(I)-mediated coupling reaction of $\mathrm{CF}_{3}\left(\mathrm{CF}_{2}\right)_{5} \mathrm{I}$ with $p$-bromoiodobenzene [10]. The route to $\mathbf{2}$ has also been used for the synthesis of $\left[\mathrm{NiCl}\left\{\mathrm{C}_{6} \mathrm{H}_{2}\left(\mathrm{CH}_{2} \mathrm{NMe}_{2}\right)_{2}-2,6-\left(\mathrm{CF}_{3}\left(\mathrm{CF}_{2}\right)_{5}\right.\right.\right.$ $\left.\left.\left.\left(\mathrm{CH}_{2}\right)_{2} \mathrm{SiMe}_{2}\right)-4\right\}\right]$, which is a model catalyst for the selective $1: 1$ Kharasch addition of $\mathrm{CCl}_{4}$ to methyl methacrylate under fluorous biphasic conditions [14]. Compounds 2 were converted

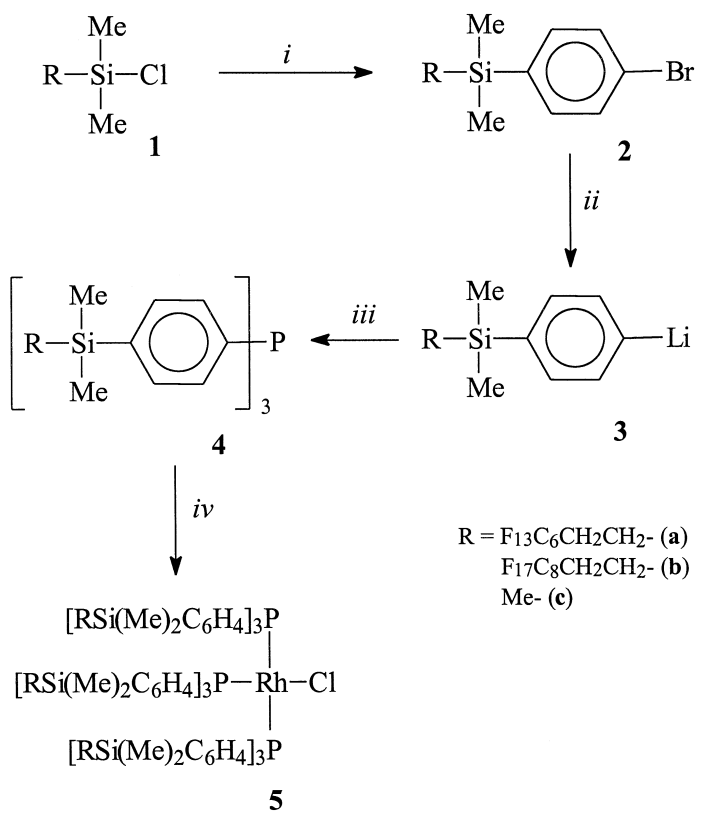

Scheme 1. Reagents and conditions: i, $\mathrm{BrC}_{6} \mathrm{H}_{4} \mathrm{Li}-4$, hexanes / THF, $-78^{\circ} \mathrm{C}$; ii, $2{ }^{t} \mathrm{BuLi}$, hexane, $0^{\circ} \mathrm{C}$ then reflux; iii, $\mathrm{P}\left(\mathrm{OR}^{\prime}\right)_{3}$ $\left(\mathrm{R}^{\prime}=\mathrm{Me}, \mathrm{Et}\right)$, pentane, $0^{\circ} \mathrm{C}$; iv, $[(\mathrm{COD}) \mathrm{RhCl}]_{2}$, benzene, room temperature. into the $p$-lithio derivatives 3 using either $t$-BuLi (1:2 molar ratio) or $n$-BuLi (1:1 molar ratio). Metathesis of 3 with $\mathrm{P}\left(\mathrm{OR}^{\prime}\right)_{3}\left(\mathrm{R}^{\prime}=\mathrm{Me}\right.$ or $\left.\mathrm{Et}\right)$ at $0^{\circ} \mathrm{C}$ afforded the ligands $\mathbf{4}^{1}$ (overall yields $33(\mathbf{4 a})$ to $75 \%(\mathbf{4 c}))$.

From comparison of the ${ }^{13} \mathrm{C}$-NMR signals of the ipso-CSiMe $2^{-}$function and the ${ }^{31} \mathrm{P}-\mathrm{NMR}$ data of compounds $4\left(\mathbf{4 a}: \delta_{\mathrm{C}} 138.7, \delta_{\mathrm{P}}-5.48\right.$;

\footnotetext{
${ }^{1} \mathbf{4 a}, \mathrm{Mp} 89^{\circ} \mathrm{C}$ (Calc. for $\mathrm{C}_{48} \mathrm{H}_{42} \mathrm{~F}_{39} \mathrm{Si}_{3} \mathrm{P}: \mathrm{C}, 39.1 ; \mathrm{H}, 2.85 ; \mathrm{F}$, 50.3; Si, 5.71; P, 2.10. Found: C, 39.3; H, 2.87; F, 50.1; Si, 5.80; $\mathrm{P}, 2.08 \%) ;{ }^{1} \mathrm{H}$ NMR $\left(300 \mathrm{MHz}, \mathrm{C}_{6} \mathrm{D}_{6}\right): \delta 7.42(\mathrm{~m}, 2 \mathrm{H}, o-\mathrm{H}$ in $\left.\mathrm{C}_{6} \mathrm{H}_{4} \mathrm{SiMe}_{2} \mathrm{C}_{6} \mathrm{~F}_{13}\right), 7.23\left(\mathrm{~m}, 2 \mathrm{H}, m-\mathrm{H}\right.$ in $\left.\mathrm{C}_{6} \mathrm{H}_{4} \mathrm{SiMe}_{2} \mathrm{C}_{6} \mathrm{~F}_{13}\right)$, $1.87(\mathrm{~m}, 2 \mathrm{H}), 0.80(\mathrm{~m}, 2 \mathrm{H}), 0.01(\mathrm{~s}, 6 \mathrm{H}) .{ }^{31} \mathrm{P}\left\{{ }^{1} \mathrm{H}\right\} \mathrm{NMR}(121.5$ $\left.\mathrm{MHz}, \mathrm{C}_{6} \mathrm{D}_{6}\right): \delta-5.48 .{ }^{13} \mathrm{C}\left\{{ }^{1} \mathrm{H}\right\} \mathrm{NMR}\left(75.5 \mathrm{MHz}, \mathrm{C}_{6} \mathrm{D}_{6}\right): \delta$ $139.4\left(\mathrm{~d},{ }^{1} J_{\mathrm{P} . \mathrm{C}}=12.7 \mathrm{~Hz}\right.$, ipso-C in $\left.\mathrm{C}_{6} \mathrm{H}_{4} \mathrm{SiMe}_{2} \mathrm{C}_{6} \mathrm{~F}_{13}\right), 138.7$ (s, ${ }^{1} J_{\mathrm{Si}, \mathrm{C}}=65 \mathrm{~Hz}, p-\mathrm{C}$, in $\left.\mathrm{C}_{6} \mathrm{H}_{4} \mathrm{SiMe}_{2} \mathrm{C}_{6} \mathrm{~F}_{13}\right), 134.3\left(\mathrm{~d},{ }^{3} J_{\mathrm{P}, \mathrm{C}}=6.7\right.$ $\mathrm{Hz}, m-\mathrm{C}$ in $\left.\mathrm{C}_{6} \mathrm{H}_{4} \mathrm{SiMe}_{2} \mathrm{C}_{6} \mathrm{~F}_{13}\right), 134.1\left(\mathrm{~d},{ }^{2} J_{\mathrm{P}, \mathrm{C}}=18.9 \mathrm{~Hz}, o-\mathrm{C}\right.$ in $\left.\mathrm{C}_{6} \mathrm{H}_{4} \mathrm{SiMe}_{2} \mathrm{C}_{6} \mathrm{~F}_{13}\right), 119.3\left(\mathrm{tt},{ }^{1} J_{\mathrm{C}, \mathrm{F}}=253.6 \mathrm{~Hz},{ }^{2} J_{\mathrm{C}, \mathrm{F}}=30.5 \mathrm{~Hz}\right.$, $\alpha-\mathrm{C}$ in $\mathrm{C}_{6} \mathrm{~F}_{13}$ ), 118.1 (qt, ${ }^{1} J_{\mathrm{C}, \mathrm{F}}=288.6 \mathrm{~Hz},{ }^{2} J_{\mathrm{C}, \mathrm{F}}=33.3 \mathrm{~Hz}$, $\mathrm{CF}_{3}$ ), 112.3 (tquin, ${ }^{1} J_{\mathrm{C}, \mathrm{F}}=268.3 \mathrm{~Hz},{ }^{2} J_{\mathrm{C}, \mathrm{F}}=32.0 \mathrm{~Hz}, \beta-\mathrm{C}$ in $\mathrm{C}_{6} \mathrm{~F}_{13}$ ), 112.1 (tquin, ${ }^{1} J_{\mathrm{C}, \mathrm{F}}=271.3 \mathrm{~Hz},{ }^{2} J_{\mathrm{C}, \mathrm{F}}=31.8 \mathrm{~Hz}, \gamma-\mathrm{C}$ in $\mathrm{C}_{6} \mathrm{~F}_{13}$ ), 111.3 (tquin, ${ }^{1} J_{\mathrm{C}, \mathrm{F}}=272.5 \mathrm{~Hz},{ }^{2} J_{\mathrm{C}, \mathrm{F}}=31.7 \mathrm{~Hz}, \delta-\mathrm{C}$ in $\mathrm{C}_{6} \mathrm{~F}_{13}$ ), $109.4\left(\mathrm{tqt},{ }^{1} J_{\mathrm{C}, \mathrm{F}}=259.6 \mathrm{~Hz},{ }^{2} J_{\mathrm{C}, \mathrm{F}}=30.5 \mathrm{~Hz}, \varepsilon-\mathrm{C}\right.$ in $\left.\mathrm{C}_{6} \mathrm{~F}_{13}\right), 26.6\left(\mathrm{t},{ }^{2} J_{\mathrm{C}, \mathrm{F}}=23.5 \mathrm{~Hz}, \mathrm{CH}_{2}\right), 5.62\left(\mathrm{~s},{ }^{1} J_{\mathrm{C}, \mathrm{Si}}=50.9 \mathrm{~Hz}\right.$, $\left.\mathrm{CH}_{2} \mathrm{Si}\right),-3.51\left(\mathrm{~s},{ }^{1} J_{\mathrm{C}, \mathrm{Si}}=53.1 \mathrm{~Hz}, \mathrm{MeSi}\right) .{ }^{19} \mathrm{~F}$ NMR $(282.4$ $\left.\mathrm{MHz}, \mathrm{C}_{6} \mathrm{D}_{6}\right): \delta-81.0\left(\mathrm{~m}, 3 \mathrm{~F}, \mathrm{CF}_{3}\right),-115.4\left(\mathrm{~m}, 2 \mathrm{~F}, \mathrm{CF}_{2} \mathrm{CH}_{2}\right)$, $-121.8\left(\mathrm{~m}, 2 \mathrm{~F}, \mathrm{CF}_{2}\right),-122.7\left(\mathrm{~m}, 2 \mathrm{~F}, \mathrm{CF}_{2}\right),-122.0(\mathrm{~m}, 2 \mathrm{~F}$, $\mathrm{CF}_{2}$ ), $-126.1\left(\mathrm{~m}, 2 \mathrm{~F}, \mathrm{CF}_{2}\right) .4 \mathbf{b}, \mathrm{Mp} 101^{\circ} \mathrm{C}$ (Calc. for $\mathrm{C}_{54} \mathrm{H}_{42} \mathrm{~F}_{51} \mathrm{Si}_{3} \mathrm{P}: \mathrm{C}, 36.5 ; \mathrm{H}, 2.34 ; \mathrm{F}, 54.6 ; \mathrm{Si}, 4.74 ; \mathrm{P}, 1.75$. Found: C, 36.6; H, 2.41; F, 54.4; $\mathrm{Si}, 4.85 ; \mathrm{P}, 1.86 \%) ;{ }^{1} \mathrm{H}$ NMR (300 MHz, $\left.\mathrm{C}_{6} \mathrm{D}_{6}\right): \delta 7.44\left(\mathrm{~m}, 2 \mathrm{H}, o-\mathrm{H}\right.$ in $\left.\mathrm{C}_{6} \mathrm{H}_{4} \mathrm{SiMe}_{2} \mathrm{C}_{6} \mathrm{~F}_{13}\right)$, $7.21\left(\mathrm{~m}, 2 \mathrm{H}, m-\mathrm{H}\right.$ in $\left.\mathrm{C}_{6} \mathrm{H}_{4} \mathrm{SiMe}_{2} \mathrm{C}_{6} \mathrm{~F}_{13}\right), 1.88\left(\mathrm{~m}, 2 \mathrm{H}, \mathrm{CH}_{2}\right)$, $0.81\left(\mathrm{~m}, 2 \mathrm{H}, \mathrm{CH}_{2} \mathrm{Si}\right), 0.02\left(\mathrm{~s}, 6 \mathrm{H},{ }^{2} J_{\mathrm{Si}, \mathrm{H}}=6.53 \mathrm{~Hz}, \mathrm{Me}\right)$. ${ }^{31} \mathrm{P}\left\{{ }^{1} \mathrm{H}\right\}$ NMR $\left(121.5 \mathrm{MHz}, \mathrm{C}_{6} \mathrm{D}_{6}\right): \delta-5.56 .{ }^{13} \mathrm{C}\left\{{ }^{19} \mathrm{~F}\right\} \mathrm{NMR}$ $\left(75.5 \mathrm{MHz}, \mathrm{C}_{6} \mathrm{D}_{6}\right): \delta 139.4\left(\mathrm{dt},{ }^{1} J_{\mathrm{P}, \mathrm{C}}=12.7 \mathrm{~Hz},{ }^{2} J_{\mathrm{C}, \mathrm{H}}=6.1 \mathrm{~Hz}\right.$, ipso-C in $\left.\mathrm{C}_{6} \mathrm{H}_{4} \mathrm{SiMe}_{2} \mathrm{C}_{6} \mathrm{~F}_{13}\right), 138.6(\mathrm{~m}, p-\mathrm{C}$, in $\left.\mathrm{C}_{6} \mathrm{H}_{4} \mathrm{SiMe}_{2} \mathrm{C}_{6} \mathrm{~F}_{13}\right), 134.3\left(\mathrm{dm}, m-\mathrm{C}\right.$ in $\left.\mathrm{C}_{6} \mathrm{H}_{4} \mathrm{SiMe}_{2} \mathrm{C}_{6} \mathrm{~F}_{13}\right), 134.1$ (dm, o-C in $\mathrm{C}_{6} \mathrm{H}_{4} \mathrm{SiMe}_{2} \mathrm{C}_{6} \mathrm{~F}_{13}$ ), 119.3 (s, $\alpha-\mathrm{C}$ in $\mathrm{C}_{6} \mathrm{~F}_{13}$ ), 118.1 $\left(\mathrm{q},{ }^{1} J_{\mathrm{C}, \mathrm{F}}=268 \mathrm{~Hz}, \mathrm{CF}_{3}\right), 112.3\left(\mathrm{~s}, \mathrm{CF}_{2}\right), 112.2\left(\mathrm{~s}, \mathrm{CF}_{2}\right), 111.8(\mathrm{~s}$, $\left.\mathrm{CF}_{2}\right), 111.7\left(\mathrm{~s}, \mathrm{CF}_{2}\right), 111.1\left(\mathrm{~s}, \mathrm{CF}_{2}\right), 109.3\left(\mathrm{qm},{ }^{2} J_{\mathrm{C}, \mathrm{F}}=26 \mathrm{~Hz}\right.$, $\eta-\mathrm{C}$ in $\left.\mathrm{C}_{6} \mathrm{~F}_{13}\right), 26.5\left(\mathrm{tt},{ }^{1} J_{\mathrm{C}, \mathrm{H}}=129.4 \mathrm{~Hz}, J=5.5 \mathrm{~Hz}, \mathrm{CH}_{2}\right)$, $5.58\left(\mathrm{t},{ }^{1} J_{\mathrm{C}, \mathrm{H}}=121.4 \mathrm{~Hz}, \mathrm{CH}_{2} \mathrm{Si}\right),-3.51\left(\mathrm{q},{ }^{1} J_{\mathrm{C}, \mathrm{H}}=119.0 \mathrm{~Hz}\right.$, $\left.\mathrm{CH}_{3} \mathrm{Si}\right) .{ }^{19} \mathrm{~F}$ NMR $\left(282.4 \mathrm{MHz}, \mathrm{C}_{6} \mathrm{D}_{6}\right): \delta-77.7\left(\mathrm{~m}, 3 \mathrm{~F}, \mathrm{C} F_{3}\right)$, $-113.0\left(\mathrm{~m}, 2 \mathrm{~F}, \alpha-\mathrm{C} F_{2}\right),-118.8\left(\mathrm{~m}, 6 \mathrm{~F}, \gamma, \delta, \varepsilon-\mathrm{C} F_{2}\right),-119.7$ $\left(\mathrm{m}, 2 \mathrm{~F}, \zeta-\mathrm{C} F_{2}\right),-120.1\left(\mathrm{~m}, 2 \mathrm{~F}, \beta-\mathrm{C} F_{2}\right),-123.1(\mathrm{~m}, 2 \mathrm{~F}$, $\eta-\mathrm{C} F_{2}$ ). 4c, Mp $194^{\circ} \mathrm{C}$, (Calc. for $\mathrm{C}_{27} \mathrm{H}_{39} \mathrm{Si}_{3} \mathrm{P}: \mathrm{C}, 67.7 ; \mathrm{H}, 8.21$; $\mathrm{Si}, 17.6 ; \mathrm{P}, 6.47$. Found: C, 67.5; H, 8.31; Si, 17.8; P, 6.58\%); ${ }^{1} \mathrm{H}$ NMR (300 MHz, $\left.\mathrm{C}_{6} \mathrm{D}_{6}\right): \delta 7.48\left(\mathrm{~m}, 2 \mathrm{H}, o-\mathrm{H}\right.$ in $\left.\mathrm{C}_{6} \mathrm{H}_{4} \mathrm{SiMe}_{3}\right)$, $7.32\left(\mathrm{~m}, 2 \mathrm{H}, m-\mathrm{H}\right.$ in $\left.\mathrm{C}_{6} \mathrm{H}_{4} \mathrm{SiMe}_{3}\right), 0.15\left(\mathrm{~s}, 9 \mathrm{H},{ }^{2} J_{\mathrm{Si}, \mathrm{H}}=6.9 \mathrm{~Hz}\right.$, Me). ${ }^{31} \mathrm{P}\left\{{ }^{1} \mathrm{H}\right\}$ NMR $\left(121.5 \mathrm{MHz}, \mathrm{C}_{6} \mathrm{D}_{6}\right): \delta-5.32 .{ }^{13} \mathrm{C}\left\{{ }^{1} \mathrm{H}\right\}$ NMR $\left(75.5 \mathrm{MHz}, \mathrm{C}_{6} \mathrm{D}_{6}\right): \delta 141.3\left(\mathrm{~s},{ }^{1} J_{\mathrm{Si}, \mathrm{C}}=64.7 \mathrm{~Hz}, p-\mathrm{C}\right.$, in $\left.\mathrm{C}_{6} \mathrm{H}_{4} \mathrm{SiMe}_{3}\right), 138.6\left(\mathrm{~d},{ }^{1} J_{\mathrm{P}, \mathrm{C}}=12.2 \mathrm{~Hz}\right.$, ipso-C in $\left.\mathrm{C}_{6} \mathrm{H}_{4} \mathrm{SiMe}_{3}\right)$, $133.8\left(\mathrm{~d},{ }^{3} J_{\mathrm{P}, \mathrm{C}}=6.6 \mathrm{~Hz}, m-\mathrm{C}\right.$ in $\left.\mathrm{C}_{6} \mathrm{H}_{4} \mathrm{SiMe}_{3}\right), 133.6\left(\mathrm{~d},{ }^{2} J_{\mathrm{P}, \mathrm{C}}=\right.$ $18.9 \mathrm{~Hz}, o-\mathrm{C}$ in $\left.\mathrm{C}_{6} \mathrm{H}_{4} \mathrm{SiMe}_{3}\right),-0.83\left(\mathrm{~s},{ }^{1} J_{S i, C}=52.3 \mathrm{~Hz}, \mathrm{Me}\right)$.
} 
4b: $\delta_{\mathrm{C}} 138.6, \quad \delta_{\mathrm{P}}-5.56 ; 4 \mathbf{c}: \delta_{\mathrm{C}} 141.3, \quad \delta_{\mathrm{P}}$ -5.32) relative to those of $\mathrm{PPh}_{3}\left(\delta_{\mathrm{C}} 128.2, \delta_{\mathrm{P}}\right.$ $-4.90)$ it can be concluded that the $-\left(\mathrm{CH}_{2}\right)_{2^{-}}$ $\mathrm{SiMe}_{2}-$ linker is very effective in insulating the electron-withdrawing perfluoroalkyl tail from the aromatic ring and consequently, the phosphorus atom. In fact, the observed ${ }^{13} \mathrm{C}$ - and ${ }^{31}$ P-NMR chemical shift differences between $\mathrm{PPh}_{3}$ and 4a,b are largely the result of the $-\mathrm{SiMe}_{2}\left(\mathrm{CH}_{2}\right)_{2}$-moiety.

As our primary objective for the perfluorotail-functionalization of triarylphosphines was to immobilize a Wilkinson-type catalyst in a fluorous solvent, solubility studies were carried out and it was found that fluorous phosphines $\mathbf{4 a , b}$ dissolve markedly better in FC-72 $\left(n-\mathrm{C}_{6} \mathrm{~F}_{14}\right)$ compared to non-fluorous $\mathrm{PPh}_{3}$ and 4c. ${ }^{2} \mathrm{Al}$ though, in an absolute sense, the fluorous phase preference of the novel phosphines is still low, it is markedly better than that of $\mathbf{4} \mathbf{c}$ and $\mathrm{PPh}_{3} \cdot{ }^{3}$

Phosphines 4 were reacted with [(COD)$\mathrm{RhCl}]_{2}$ to afford the tris(triarylphosphine)rhodium(I) chlorides 5 (Scheme 1, step iv). Complexes $\mathbf{5 a}, \mathbf{b}$, isolated as red oils, were purified by washing with hexane or toluene. Non-fluorous 5c was obtained as an orange powder which needed no further purification. The crude reaction mixtures also contained dimeric byproduct $[(\mathrm{COD}) \mathrm{RhCl}(4)]_{2}$ (typically $20-30 \%$ ). An alternative route to compounds $\mathbf{5 a}, \mathbf{b}$ involves treatment of $\left[\mathrm{RhCl}\left(\mathrm{PPh}_{3}\right)_{3}\right]$ with $\mathbf{4 a}, \mathbf{b}$ in benzene at room temperature to produce $\mathbf{5 a}, \mathbf{b}$ in essentially quantitative yield. All three complexes $\mathbf{5}$ were fully characterized by NMR spectroscopy $\left({ }^{1} \mathrm{H},{ }^{13} \mathrm{C},{ }^{31} \mathrm{P}\right)$ and gave satisfactory

\footnotetext{
${ }^{2}$ e.g., the solubility of $\mathbf{4 b}$ in FC-72 $(\sim 30 \mathrm{mM})$ is at least 40 times higher than that of $\mathrm{PPh}_{3}$ and seven times higher than that of 4c. Although the relative solubility of $\mathbf{4 b}$ in FC-72 compared to pentane is low $\left(c_{\mathrm{FC}-72} / c_{\text {pentane }}=0.14\right)$, it is more than 25 times higher than that of $\mathrm{PPh}_{3}$ (insoluble in FC-72) and three times better than that of $4 \mathbf{c}\left(c_{\mathrm{FC}-72} / c_{\text {pentane }}<0.005\right.$ and $<0.044$, respectively).

${ }^{3}$ i.e., 1.3:1 (4b) and $>90: 1$ (4c) distributions in favor of the hexane layer were found at $10^{\circ} \mathrm{C}$ in $1: 1(\mathrm{v} / \mathrm{v})$ biphasic mixtures of $n$-hexane and FC-72 $\left(T_{\mathrm{c}}=23^{\circ} \mathrm{C}\right)$.
}

elemental analyses. ${ }^{4}$ From the ${ }^{31} \mathrm{P}$ NMR data, it can be concluded that complexes 5 adopt square planar geometries similar to the original Wilkinson's catalyst [15]. Solubility studies with $\mathbf{5 b}$ in pure FC-72, $n$-hexane or benzene indicate that in contrast to the free fluorous phosphines, the fluorous rhodium complex $\mathbf{5 b}$ has high fluor phase solubility at room temperature despite its high molecular weight. ${ }^{5}$

Rhodium complexes $\mathbf{5 a}, \mathbf{b}$ were found to be active catalysts for solution phase hydrogenation of 1-alkenes under single phase conditions. ${ }^{6}$ Using $\alpha, \alpha, \alpha$-trifluorotoluene as solvent, it was

\footnotetext{
${ }^{4}$ 5a, (Calc. for $\mathrm{C}_{144} \mathrm{H}_{126} \mathrm{~F}_{117} \mathrm{ClSi}_{9} \mathrm{P}_{3} \mathrm{Rh}$ : C, 37.9; H, 2.78; F, 48.7; Cl, 0.78; Si, 5.54; P, 2.04. Found: C, 37.8; H, 2.85; F, 48.5; $\mathrm{Si}, 5.61 ; \mathrm{P}, 2.11 \%) ;{ }^{1} \mathrm{H}$ NMR (300 MHz, FC-72/C $\left.{ }_{6} \mathrm{D}_{6}\right): \delta 7.61$ $\left(\mathrm{m}, 18 \mathrm{H}, o-\mathrm{H}\right.$ in $\left.\mathrm{C}_{6} \mathrm{H}_{4} \mathrm{SiMe}_{2} \mathrm{C}_{6} \mathrm{~F}_{13}\right), 6.97(\mathrm{~m}, 18 \mathrm{H}, m-\mathrm{H}$ in $\left.\mathrm{C}_{6} \mathrm{H}_{4} \mathrm{SiMe}_{2} \mathrm{C}_{6} \mathrm{~F}_{13}\right), 1.87\left(\mathrm{~m}, 18 \mathrm{H}, \mathrm{CH}_{2} \mathrm{CF}_{2}\right), 0.80(\mathrm{~m}, 18 \mathrm{H}$, $\left.\mathrm{CH}_{2} \mathrm{Si}\right), 0.04(\mathrm{~m}, 54 \mathrm{H}, \mathrm{Me}) .{ }^{31} \mathrm{P}\left\{{ }^{1} \mathrm{H}\right\}$ NMR $(121.5 \mathrm{MHz}$, $\left.\mathrm{CF}_{3} \mathrm{C}_{6} \mathrm{H}_{5} / \mathrm{C}_{6} \mathrm{D}_{6}\right): \delta 48.0\left(\mathrm{dt},{ }^{1} J_{\mathrm{Rh}, \mathrm{P}}=189.9 \mathrm{~Hz},{ }^{2} J_{\mathrm{P}, \mathrm{P}}=37.6\right.$ $\mathrm{Hz}), 31.42\left(\mathrm{dd},{ }^{1} J_{\mathrm{Rh}, \mathrm{P}}=143.3 \mathrm{~Hz},{ }^{2} J_{\mathrm{P}, \mathrm{P}}=37.6 \mathrm{~Hz}\right.$ ). 5b, (Calc. for $\mathrm{C}_{162} \mathrm{H}_{126} \mathrm{~F}_{153} \mathrm{ClSi}_{9} \mathrm{P}_{3} \mathrm{Rh}$ : C, 35.6; $\mathrm{H}, 2.32$; F, 53.2; Si, 4.63; P, 1.70. Found: C, 35.7; H, 2.37; F, 53.0; Si, 4.66; P, $1.65 \%) ;{ }^{1} \mathrm{H}$ NMR (300 MHz, $\left.\mathrm{CF}_{3} \mathrm{C}_{6} \mathrm{~F}_{14} / \mathrm{C}_{6} \mathrm{D}_{14}\right): \delta 7.43(\mathrm{~m}, 18 \mathrm{H}, o-\mathrm{H}$ in $\left.\mathrm{C}_{6} \mathrm{H}_{4} \mathrm{SiMe}_{2} \mathrm{C}_{8} \mathrm{~F}_{17}\right) 7.00\left(\mathrm{~m}, 18 \mathrm{H}, m-\mathrm{H}\right.$ in $\left.\mathrm{C}_{6} \mathrm{H}_{4} \mathrm{SiMe}_{2} \mathrm{C}_{8} \mathrm{~F}_{17}\right)$, $1.89\left(\mathrm{~m}, 18 \mathrm{H}, \mathrm{CH}_{2} \mathrm{CF}_{2}\right), 0.85\left(\mathrm{~m}, 18 \mathrm{H}, \mathrm{CH}_{2} \mathrm{Si}\right), 0.15(\mathrm{~m}, 54 \mathrm{H}$, Me). ${ }^{31} \mathrm{P}\left\{{ }^{1} \mathrm{H}\right\} \mathrm{NMR}\left(121.5 \mathrm{MHz}, \mathrm{CF}_{3} \mathrm{C}_{6} \mathrm{H}_{5} / \mathrm{C}_{6} \mathrm{D}_{6}\right): \delta 48.0(\mathrm{dt}$, $\left.{ }^{1} J_{\mathrm{Rh}, \mathrm{P}}=191.9 \mathrm{~Hz},{ }^{2} J_{\mathrm{P}, \mathrm{P}}=37.4 \mathrm{~Hz}\right), 31.42\left(\mathrm{dd},{ }^{1} J_{\mathrm{Rh}, \mathrm{P}}=144.6\right.$ $\left.\mathrm{Hz},{ }^{2} J_{\mathrm{P}, \mathrm{P}}=37.4 \mathrm{~Hz}\right) .{ }^{13} \mathrm{C}\left\{{ }^{1} \mathrm{H}\right\} \quad \mathrm{NMR} \quad(75.5 \mathrm{MHz}$, $\left.\mathrm{CF}_{3} \mathrm{C}_{6} \mathrm{~F}_{14} / \mathrm{C}_{6} \mathrm{D}_{14}\right): \delta$ 138.7, 138.4, 137.0, 135.3, 134.7, 132.4, 128.7, $126-102\left(\mathrm{~m}, \mathrm{CF}_{3}, \mathrm{CF}_{2}\right), 26.4\left(\mathrm{t},{ }^{2} J_{\mathrm{C}, \mathrm{F}}=23.8 \mathrm{~Hz}\right.$, $\left.\mathrm{CH}_{2} \mathrm{CF}_{2}\right), 5.51\left(\mathrm{~s}, \mathrm{CH}_{2} \mathrm{Si}\right),-4.35\left(\mathrm{~s},{ }^{1} J_{\mathrm{C}, \mathrm{Si}}=52.6 \mathrm{~Hz}, \mathrm{Me}\right) .5 \mathbf{c}$, (Calc. for $\mathrm{C}_{81} \mathrm{H}_{117} \mathrm{ClSi}_{9} \mathrm{P}_{3} \mathrm{Rh}$ : C, 61.8; H, 7.49; Si, 16.0; P, 5.90. Found: C, 61.6; H, 7.56; Si, 15.8; P, 5.94\%); ${ }^{1} \mathrm{H}$ NMR $(200 \mathrm{MHz}$, $\left.\mathrm{C}_{6} \mathrm{D}_{6}\right): \delta 7.9\left(\mathrm{~m}, 18 \mathrm{H}, o-\mathrm{H}\right.$ in $\left.\mathrm{C}_{6} \mathrm{H}_{4} \mathrm{SiMe}_{3}\right), 7.2(\mathrm{~m}, 18 \mathrm{H}, m-\mathrm{H}$ in $\left.\mathrm{C}_{6} \mathrm{H}_{4} \mathrm{SiMe}_{3}\right), 0.18(\mathrm{~m}, 54 \mathrm{H}, \mathrm{Me}) .{ }^{31} \mathrm{P}\left\{{ }^{1} \mathrm{H}\right\} \mathrm{NMR}(81.0 \mathrm{MHz}$, $\left.\mathrm{C}_{6} \mathrm{D}_{6}\right): \delta 47.4 .0\left(\mathrm{dt},{ }^{1} J_{\mathrm{Rh}, \mathrm{P}}=191.8 \mathrm{~Hz},{ }^{2} J_{\mathrm{P}, \mathrm{P}}=37.5 \mathrm{~Hz}\right), 31.0$ $\left(\mathrm{dd},{ }^{1} J_{\mathrm{Rh}, \mathrm{P}}=143.4 \mathrm{~Hz},{ }^{2} J_{\mathrm{P}, \mathrm{P}}=37.5 \mathrm{~Hz}\right) .{ }^{13} \mathrm{C}\left\{{ }^{1} \mathrm{H}\right\} \mathrm{NMR}(75.5$ $\left.\mathrm{MHz}, \mathrm{C}_{6} \mathrm{D}_{6}\right): \delta$ 141.3, 141.0, $137.1(\mathrm{~m}), 135.5(\mathrm{~m}), 134.7(\mathrm{~d})$, $133.8(\mathrm{~d}), 132.7(\mathrm{~m}), 132.1(\mathrm{~d}),\left(\mathrm{C}_{6} \mathrm{H}_{4}\right),-0.75\left(\mathrm{~s},{ }^{1} J_{\mathrm{C}, \mathrm{Si}}=52.5\right.$ $\mathrm{Hz}, \mathrm{Me})$.

${ }^{5}>20 \mathrm{mM}$ (FC-72) vs. 0.33 (benzene) and $5.80 \mathrm{mM}$ (hexane).

${ }^{6}$ A representative catalytic reaction under single phase fluorous conditions was carried out in $c-\mathrm{CF}_{3} \mathrm{C}_{6} \mathrm{~F}_{11}(2 \mathrm{ml})$ at $80^{\circ} \mathrm{C}$ and atmospheric hydrogen pressure using $0.035 \mathrm{mmol}$ of catalyst and $12.7 \mathrm{mmol}$ of 1-octene. The hydrogen atmosphere was maintained by an oil filled calibrated gas burette charged with $\mathrm{H}_{2}$. To recycle the catalyst layer after $>95 \%$ conversion (monitored by the $\mathrm{H}_{2}$ uptake), the homogeneous reaction mixture was cooled to $0^{\circ} \mathrm{C}$, the upper organic layer was siphoned off and a new quantity of 1-octene was added. Activity is expressed as the turn-over frequency (TOF): mol of $\mathrm{H}_{2} \cdot$ consumed $\mathrm{mol}^{-1}$ of $\mathrm{Rh} \mathrm{h}^{-1}$. Turn-over number (TON): mol of $\mathrm{H}_{2} \cdot$ consumed $\mathrm{mol}^{-1} \mathrm{Rh}$.
} 
possible to compare activities of the fluorous and non-fluorous catalysts. From Fig. 1, it can be concluded that introducing and/or lengthening of the fluor tail has a negative effect on activity in comparison with the trimethylsilyl derivative 5c. However, activities are close to that of the conventional Wilkinson's catalyst.

With perfluoromethylcyclohexane as fluorous solvent the hydrogenation products can be readily isolated from the catalyst layer by cooling the reaction mixture below $25^{\circ} \mathrm{C}$ followed by phase separation of the resulting biphasic system. In this way, hydrogenation of 1-octene afforded $n$-octane in $>95 \%$ isolated yield (GC). For $\mathbf{5 b}$, we were able to recycle the fluorous catalyst layer multiple times allowing high turnover numbers (TON $>3000$ in nine cycles). Upon recycling of the catalyst layer, it was found that the activity increased $(\mathrm{TOF}=177$ $\mathrm{h}^{-1}$ in the first cycle, TOF $=600 \mathrm{~h}^{-1}$ in the eighth cycle) which is most probably caused by the combined effects of a non-zero order rate dependence in rhodium and the (observed) loss of fluorous solvent due to non-zero miscibility of $c-\mathrm{CF}_{3} \mathrm{C}_{6} \mathrm{~F}_{11}$ in the product layer even at $0^{\circ} \mathrm{C}$. Restoring the amount of $c-\mathrm{CF}_{3} \mathrm{C}_{6} \mathrm{~F}_{11}$ to its original value reproduced $87 \%$ of the initial activity $\left(\mathrm{TOF}=155 \mathrm{~h}^{-1}\right)$ in the ninth cycle. It should be clear, however, that the effect of traces of air and moisture cannot be completely excluded at this experimental scale.

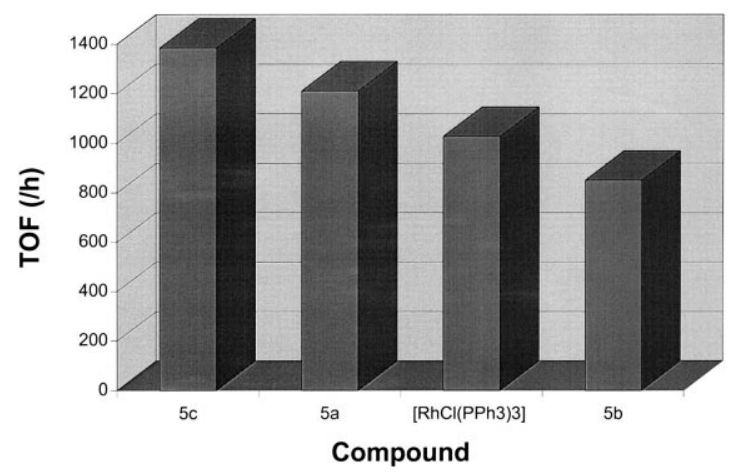

Fig. 1. Turn-over frequencies (TOF, expressed as mol of $\mathrm{H}_{2}$ consumed $\mathrm{mol}^{-1}$ of $\mathrm{Rh} \mathrm{h}^{-1}$ ) for the non-fluorous and the newly developed fluorous hydrogenations catalysts. Conditions: $T=$ $80^{\circ} \mathrm{C}, p=1$ bar, solvent: $\mathrm{CF}_{3} \mathrm{C}_{6} \mathrm{H}_{5}$.
As was anticipated by the limited drop in activity upon recycling of the catalyst, ICP-AAS analysis confirmed that leaching of rhodium into the product layer is low (5a: $0.3 \%(6 \mathrm{ppm})$; 5b: $0.1 \%(3 \mathrm{ppm})$ after the first cycle and $1.0 \%$ after nine cycles; $T=0^{\circ} \mathrm{C}$ ) demonstrating the high fluor phase preference of the rhodium containing species. It should be noted, however, that efficient retention of fluorous phosphine is just as important for recycling the intact catalyst system as is retention of rhodium. In fact, significant amounts of fluorous phosphine were present in the alkane product phases (5a: 130 ppm, 0.24 equiv. per Rh; 5b: 56 ppm, 0.07 equiv. per $\mathrm{Rh}$ ) indicating that leaching of fluorous ligand is more significant than that of rhodium itself. A monomer-dimer equilibrium involving dissociation of phosphine as is known for the original Wilkinson's catalyst $[11,12]$ may well be responsible for this.

\section{Conclusion}

In conclusion, we have demonstrated a straightforward synthetic route for the synthesis of novel fluorous triaryl phosphines and derived Wilkinson-type catalysts. The fluorous Wilkinson's catalysts display high activity in the hydrogenation of 1-alkenes under fluorous conditions and it was found that the fluorous catalyst 5b can be recycled effectively for at least eight times with an overall recovery of rhodium of $99 \%$ and less than $13 \%$ drop in activity. For an even higher fluor phase retention of these hydrogenation catalysts, it will probably be worthwhile to decrease the solubility of (especially) the phosphine ligands in the organic phase even further. To this end, studies directed to further increase the fluorous nature of the phosphine ligands are in progress.

\section{Acknowledgements}

We thank H. Kleijn and Dr. J.T.B.H. Jastrzebski (Utrecht University) for valuable advise 
and Elf Atochem Vlissingen for financial support. B.R. also thanks U-Cat (Utrecht) for financial support.

\section{References}

[1] I.T. Horváth, J. Rábai, Science 266 (1994) 72.

[2] I. Horváth, J. Rábai, Eur. Pat. Appl., EP 94-304877.7, US pat. 93-88706.

[3] S. Kainz, D. Koch, W. Baumann, W. Leitner, Angew. Chem. Int. Ed. Engl. 36 (1997) 1628.

[4] I.T. Horváth, G. Kiss, R.A. Cook, J.E. Bond, P.A. Stevens, J. Rábai, E.J. Mozeleski, J. Am. Chem. Soc. 120 (1998) 3133.

[5] J.J.J. Juliette, I.T. Horváth, J.A. Gladysz, Angew. Chem. Int. Ed. Engl. 36 (1997) 1610.

[6] A.M. Stuart, E.G. Hope, R.D.W. Kemmit, D.R. Paige, 11th
International Symposium on Homogeneous Catalysis, University of St. Andrews, Scotland, UK, 12-17 July 1998.

[7] B. Betzemeier, P. Knochel, Angew. Chem. Int. Ed. Engl. 36 (1997) 2623.

[8] M.A. Caroll, A.B. Holmes, Chem. Commun. (1998) 1395.

[9] H. Gopal, C.E. Snyder, C. Tamborski, J. Fluorine Chem. 14 (1979) 511

[10] P. Bhattacharya, D. Gudmunsen, E.G. Hope, R.D.W. Kemmitt, D.R. Paige, A.M. Stuart, J. Chem. Soc., Perkin Trans. I (1997) p. 3609.

[11] F.H. Jardine, J.A. Osborn, G. Wilkinson, J. Chem. Soc., (A) (1967), p. 1574.

[12] A. Montelatici, A. van der Ent, J.A. Osborn, G. Wilkinson, J. Chem. Soc., (A) (1968) p. 1054 and references therein.

[13] K.C. Frisch, H. Lyons, J. Am. Chem. Soc. 75 (1953) 4078.

[14] H. Kleijn, J.T.B.H. Jastrzebski, R.A. Gossage, H. Kooijman, A.L. Spek, G. van Koten, Tetrahedron 54 (1997) 1145.

[15] M.J. Bennett, P.B. Donaldson, Inorg. Chem. 16 (1977) 655. 